\title{
FLCN wt Allele
}

National Cancer Institute

\section{Source}

National Cancer Institute. FLCN wt Allele. NCI Thesaurus. Code C63517.

Human FLCN wild-type allele is located in the vicinity of $17 p 11.2$ and is approximately 25 $\mathrm{kb}$ in length. This allele, which encodes folliculin protein may play a role in tumor suppression, but an exact function has yet to be identified. Mutations or aberrations in the gene result in Birt-Hogg-Dube syndrome. 